\title{
Formation of Erysiphe necator Chasmothecia in the Pacific Northwest United States
}

\author{
L. D. Thiessen, ${ }^{1, \dagger}$ T. M. Neill, ${ }^{2}$ and W. F. Mahaffee ${ }^{2}$ \\ ${ }^{1}$ Oregon State University, Department of Botany and Plant Pathology, Corvallis, OR 97331; and ${ }^{2}$ U.S. Department of \\ Agriculture-Agricultural Research Service, Horticultural Crops Research Laboratory, Corvallis, OR 97330
}

\begin{abstract}
In the Pacific Northwest, chasmothecia formation is not observed in vineyards until the beginning of véraison despite heavy infestations whereby $100 \%$ of leaf tissue is covered by Erysiphe necator. Mating type proximity and distribution were sampled from individual lesions $\left(\sim 71 \mathrm{~mm}^{2}\right)$ on leaf tissue in a stratified sampling from three canopy heights at three times during the 2013, 2014, and 2015 growing seasons. Both mating types were observed at every sampling point and within the same lesions at all sampling dates and canopy heights. Effect of temperature and day length were examined by inoculating seedlings with known mating type 1 and 2 isolates and placed in incubators at different temperatures $\left(5,10,15,20,25\right.$, and $\left.30^{\circ} \mathrm{C}\right)$ or different day length changes (long day to long day, long day to short day, short day to short day,

and short day to long day). Chasmothecia were produced at all temperatures that $E$. necator was able to colonize tissue, and the greatest number of chasmothecia were produced at 15 and $20^{\circ} \mathrm{C}(P \leq 0.02)$. Day length shifts from short day $(8 \mathrm{~h})$ to long day $(16 \mathrm{~h})$ resulted in a significant increase in chasmothecia production $(P<0.001)$. End of season plant stress observed in the Pacific Northwest, such as water stress or host senescence, was assessed under naturally infested field conditions by either girdling canes or applying $150 \mathrm{mg} \cdot \mathrm{liter}^{-1} \mathrm{absci}^{-}$ sic acid solution to vines, respectively, and quantifying chasmothecia production. No differences were observed in chasmothecia production in the plant stress assessment, likely due to the high vigor and ability for plants to overcome stress treatments.
\end{abstract}

Grape powdery mildew, caused by Erysiphe necator Schwein. (Braun and Takamatsu 2013), is a polycyclic disease of Vitaceae, and causes economic damage in every region where grape is produced. The disease cycle is most commonly initiated in the spring by ascospores that are released from chasmothecia when they are exposed to conducive environmental conditions, such as free moisture and temperatures above $4^{\circ} \mathrm{C}$ (Gadoury and Pearson 1990). These conditions are common throughout the dormancy of grapevine in the Mediterranean climate (Csb) of the Pacific Northwest United States, which is characterized by a warm, temperate climate with warm, dry summers and moderate, wet winters (Kottek et al. 2006). The environmental conditions in the Csb region, also common to parts of the Mediterranean, South America, and Australia, may impact the release of ascospores and act to deplete potential inoculum prior to bud break (BBCH 08) (Lorenz et al. 1995). In the Pacific Northwest and similar growing regions, ascospore release begins with fall rains and continues throughout host dormancy and into the growing season (Caffi et al. 2011; Gee et al. 2000; Thiessen et al. 2018). Ascospores have been described as the primary inoculum, initiating the disease epidemic each season (Caffi et al. 2011, 2012; Cortesi et al. 1997; Gadoury and Pearson 1988; Gee et al. 2000; Legler et al. 2012, 2014; Pscheidt et al. 2000; Rossi et al. 2010). Several models have been developed to predict the occurrence and magnitude of ascospore release to generate management decision aids (Caffi et al. 2011; Gadoury and Pearson 1990; Moyer et al. 2014; Thomas et al. 1994); however, these models inaccurately predict ascospore release in the Willamette Valley of Oregon (Thiessen et al. 2018). These inaccuracies may be a function of regional climatic conditions that influence chasmothecia and ascospore production and maturation.

${ }^{\dagger}$ Corresponding author: L. D. Thiessen; E-mail: 1dthiess@ncsu.edu

Funding: This work was supported by the American Vineyard Foundation, the Oregon Wine Board, and USDA-ARS CRIS 5358-22000-039-00D.

Accepted for publication 24 October 2018.

() 2019 The American Phytopathological Society
The initiation of E. necator chasmothecia requires hyphal fusion of opposite mating types, Mat 1-1 and Mat 1-2 (Gadoury and Pearson 1988, 1991; Gee et al. 2000), and occurs in some regions as soon as both mating types are in contact (Gadoury and Pearson 1988) or, in other regions, forming after véraison (Bulit and Lafon 1978; Jailloux et al. 1998; Legler et al. 2014). In the Willamette Valley of Oregon (L. D. Thiessen, personal observation), chasmothecia have only been observed to form around the beginning of véraison, despite heavy infestations ( $>90 \%$ of leaf surface area) on individual leaves similar to observations in other Mediterranean climates (Legler et al. 2012). The proximity of $E$. necator colonies to those of the opposite mating type is suggested as an explanation for the late formation of chasmothecia in other heterothallic species (Byford and Bentley 1976; Gadoury and Pearson 1988; Smith 1970); however, the dynamic temporal distribution of mating types within a vineyard and on the leaf surface has not yet been investigated. In order to assess the role of mating type proximity when chasmothecia form, the spatial and temporal distribution of E. necator mating types needs to be examined in the field.

In addition to mating type proximity, environmental conditions may significantly influence the initiation of chasmothecia. Temperatures that are outside the range of growth of E. necator $\left(9-35^{\circ} \mathrm{C}\right)$ (Delp 1954) also reduce the development of chasmothecia, but chasmothecia development was observed at all temperatures that E. necator is capable of hyphal growth (Gadoury and Pearson 1988). Humidity and photoperiod were also not correlated with the initiation of chasmothecia formation on tissue culture plants and detached leaves (Gadoury and Pearson 1988); however, tissue culture and detached leaves require wounding plant tissues, which could induce physiological changes in the plant tissue and impact development of chasmothecia (León et al. 2001). Because E. necator has closely evolved with grapevine and the haustoria produced by the fungus interact closely with host plants (Mendgen and Hahn 2002), the host integrity during testing may have a strong influence on the formation of chasmothecia. Injury of plant tissues for tissue culture or detached leaf assays may cause an upregulation of host defense compounds that are not observed when testing whole plants (Bowles 1990), causing differences in growth of E. necator. Similarly, growth regulatory hormone signaling found during stressful conditions, such as production of abscisic acid during drought conditions (Boneh et al. 2012; Skriver and Mundy 1990), may be differentially expressed in vines 
found in field environments compared with tissue culture or detached leaves used in laboratory experiments, which may influence the development of $E$. necator chasmothecia. Host signaling during stress or host senescence has been previously suggested as a factor in the initiation of ascocarp formation of some powdery mildew species (Homma 1937), and may elucidate the late development of chasmothecia observed in the Pacific Northwest.

To understand the factors influencing chasmothecia initiation, such as mating type proximity, environmental conditions, and host stress factors, field and growth chamber studies were designed to isolate the effects of environmental and host influences. The specific objectives for this study were to 1) evaluate mating type spatial and temporal distribution within a vineyard, 2) determine if the initiation of chasmothecia is dependent on environmental cues when whole plants are inoculated with both mating types of E. necator, and 3) examine potential stress effects or host signaling on chasmothecia initiation in both field and growth chamber trials.

\section{Materials and Methods}

Mating type field survey. To determine if chasmothecia development in the field is related to mating type proximity, E. necator samples were collected at three time points during the period of active mildew management (April-August) in 2013, 2014, and 2015 (early: 9 leaves unfolded [BBCH 19], midseason: inflorescence swelling [BBCH 55], and late: berry touch [BBCH 77]) from nontreated bilateral vertical shoot-positioning, cane-pruned Pinot Noir Clone 2A vines on 420A rootstock at the Botany and Plant Pathology Research Vineyard (Corvallis, OR). At each sampling time, the canopy was divided into equal thirds (upper, middle, and lower), and 20 samples were collected along three rows $(54 \mathrm{~m})$ of grapevines chosen at random with only one sample collected from each zone for any single vine. A sample was collected by placing and removing a $\sim 70.9 \mathrm{~mm}^{2}$ Tough-Spots microcentrifuge tube label (Diversified Biotech, Dedham, MA) onto a leaf such that individual E. necator colonies were collected. The Tough-Spots label was then placed in a sterile $2 \mathrm{ml}$ microcentrifuge tube and stored at $-20^{\circ} \mathrm{C}$ until processing.

DNA extraction of samples was modified from Brewer and Milgroom (2010). After samples were frozen, $200 \mu \mathrm{l}$ of Chelex 100 (Sigma Aldrich, St. Louis, MO, USA) in DEPC-treated water (Growcells, Irvine, CA) was added to each sample tube, vortexed horizontally for $5 \mathrm{~min}$, and then centrifuged briefly at $10,000 \times g$ to move contents to the tube bottom. Tubes were incubated at $95^{\circ} \mathrm{C}$ for $10 \mathrm{~min}$, vortexed for $5 \mathrm{~s}$, centrifuged again to move contents to the tube bottom, and again incubated at $95^{\circ} \mathrm{C}$ for $10 \mathrm{~min}$. After the second incubation, tubes were allowed to cool to room temperature for approximately $20 \mathrm{~min}$, then centrifuged for $2 \mathrm{~min}$, and the liquid was transferred from the extraction tube to a sterile microcentrifuge tube before running the PCR analysis.

To assess mating types (Mat 1-1 and 1-2) of field collected colonies, multiplex PCR of field samples utilized the $E n \alpha F 2, E n \alpha R 3$, EnHMGF1, and EnHMGR1 primers developed by Brewer et al. (2011), which target the mating type genes at the Mat 1 locus of E. necator. PCR reactions were conducted in a total volume of $25 \mu \mathrm{lus}-$ ing Accustart II PCR ToughMix (Quanta Biosciences, Gaithersburg, MD, USA), nuclease-free DEPC-treated water, En $\alpha \mathrm{F} 2(0.4 \mu \mathrm{M})$, En $\alpha$ R3 $(0.4 \mu \mathrm{M})$, EnHMGF1 $(0.4 \mu \mathrm{M})$, EnHMGR1 $(0.4 \mu \mathrm{M})$, and $1 \mu \mathrm{l}$ of template DNA. Cycling conditions included an initial denaturation at $94^{\circ} \mathrm{C}$ for $2 \mathrm{~min}$ followed by 40 cycles of a template denaturation step at $94^{\circ} \mathrm{C}$ for $30 \mathrm{~s}$, an annealing step at $55^{\circ} \mathrm{C}$ for $30 \mathrm{~s}$, and an extension step at $68^{\circ} \mathrm{C}$ for $30 \mathrm{~s}$. Following a final extension at $68^{\circ} \mathrm{C}$ for $7 \mathrm{~min}$, reactions were kept at $10^{\circ} \mathrm{C}$ until processed with gel electrophoresis. Each PCR product $(10 \mu \mathrm{l})$ with loading dye was analyzed using electrophoresis through a $2 \%(\mathrm{wt} / \mathrm{vol})$ agarose/TAE gel containing ethidium bromide $(1 \mu \mathrm{g} / \mathrm{ml})$. To confirm primer specificity of the mating type primers, a subsample of the PCR amplicons from Mat 1-1 and Mat 1-2 primer sets were sequenced using Sanger sequencing at the Oregon State University Center for Genome Research and Biocomputing Core Laboratory (Corvallis, OR).

Effect of environmental conditions on seedlings. Because detached leaf assays and tissue culture plants may have unknown effects on obligate fungal growth, growth chamber experiments were designed to determine the effect of environmental conditions on infection of whole plants grown from seed. Chardonnay seeds were collected from crush pomace, washed, and stored at $4{ }^{\circ} \mathrm{C}$ until used. Prior to planting, seeds were scarified by soaking in $9 \% \mathrm{H}_{2} \mathrm{O}_{2}$ for $48 \mathrm{~h}$ at room temperature, rinsed with deionized water, and resuspended in deionized water for $48 \mathrm{~h}$ at room temperature. Seeds were rinsed again with deionized water and soaked in a suspension of Switch $(488 \mu \mathrm{g} / \mathrm{ml}$ Cyprodinil and $488 \mu \mathrm{g} / \mathrm{ml}$ Fludiononil) and Abound fungicides (224 $\mu \mathrm{g} / \mathrm{ml}$ Azoxystrobin) (Syngenta, Greensboro, NC) for $10 \mathrm{~min}$. Seeds were spread on moistened filter paper and stored in the dark at $20^{\circ} \mathrm{C}$. After 1 week, germinated seed were planted into potting mix (28.8\% peat: $45.2 \%$ perlite: $26 \%$ vermiculite) in 10-cm pots and grown in the greenhouse until use.

$E$. necator isolates were maintained on detached surfacedisinfested, $V$. vinifera 'Chardonnay' leaves in double-stacked petri dishes (Quinn and Powell 1982). Isolate mating types were periodically tested using primers described above to confirm their mating type identity. Seedlings with 3 true leaves were inoculated with both Mat 1-1 and Mat 1-2 E. necator isolates by spreading conidia over two fully expanded leaf surfaces with sterile paint brushes. Plants were placed into growth chambers $\left(0.6 \mathrm{~m}^{2}\right)$ with cool-white fluorescent and incandescent light bulbs programmed for photoperiod, humidity, and temperature as described below. Plants were watered and fertilized (24-8-16) every 2 weeks to maintain optimal growth.

Effect of temperature. Growth chambers for inoculated seedlings with 3 true leaves were held at $60 \%$ humidity and 16-h days with 8 -h dark periods. The temperature in each chamber was set to 5 , $10,15,20,25,30$, or $35^{\circ} \mathrm{C}$. Each growth chamber with 3 subsamples (seedlings) served as the experimental unit, and the temperature trial was replicated three times. Leaves were monitored for disease progression and chasmothecia development daily for 42 days postinoculation, and chasmothecia were enumerated by counting the number of ascocarps (primordia, immature, and melanized) on inoculated leaves at each monitoring date.

Effect of photoperiod. To determine if change in the photoperiod length affected chasmothecia formation, four photoperiod shift regimes were used. Seedling with 3 true leaves were grown for 14 days at either short day ( $8 \mathrm{~h}$ of light and $16 \mathrm{~h}$ of darkness) or long day ( $16 \mathrm{~h}$ of light and $8 \mathrm{~h}$ of darkness) photoperiods before inoculations as above. Plants were then inoculated and incubated for 14 days at the initial photoperiod before being switched to a long day or short day photoperiod for the remainder of the experiment. This design resulted in 4 treatments: long day to long day, long day to short day, short day to short day, and short day to long day. All growth chambers were programed for $60 \%$ humidity and $20^{\circ} \mathrm{C}$. An experimental unit consisted of 3 vines per light photoperiod shift regime. The entire experiment was replicated three times. Leaves were monitored daily until 35 days postinoculation for disease progression and chasmothecia development, and chasmothecia were enumerated as above at each date of monitoring.

Effect of plant stress on chasmothecia initiation. To assess the development of chasmothecia in the field, a research vineyard containing bilateral vertical shoot-positioning, cane-pruned $\mathrm{CH}-76$ Chardonnay vines on 101-14 rootstock was used for all field testing. To ensure that both mating types were available throughout the duration of the growing season, a liquid suspension containing both mating types was applied until just before runoff at growth stage BBCH 19 using a Preval Aerosol Sprayer (Chicago, IL). The conidia were mechanically separated from leaves in $0.05 \%$ Tween 20 (Sigma Aldrich, St. Louis, MO, USA) and sterile deionized water solution and mixed at 1:1 ratio of each mating type with $2 \times 10^{3}$ conidia/ $\mathrm{ml}$. The conidia suspension was applied to field plants within $1 \mathrm{~h}$ of preparation to maintain conidia viability.

To test host stress induction of chasmothecia, vines were either girdled or sprayed with abscisic acid solution (ABA) at two different time periods (BBCH 75 and $\mathrm{BBCH} 79)$. Girdling was done by removing a 1-cm-wide section of vascular cambium from the circumference of both fruiting canes. A $150 \mathrm{mg} \cdot \mathrm{liter}^{-1}$ ABA solution was applied using a Preval Aerosol Sprayer to cover the surface of all 
green tissues of vines within a plot. Nontreated control plots were used to compare natural chasmothecia development to stress-induction treatments. All treatments were applied to three replications using a randomized complete block design. Each replication consisted of 5 Chardonnay vines $(1.5 \times 2.1 \mathrm{~m}$ spacing $)$ with $101-14$ rootstock vines separating plots.

Disease was monitored through weekly scouting for visual signs of disease on leaf and fruit tissues beginning 1 week after field inoculation occurred. Leaves were collected as soon as chasmothecia primordia were observed on them in the field (BBCH 91) in each year, which occurred August 23, 2013 and August 28, 2014. Ten leaves were randomly sampled weekly from the middle of the canopy regardless of leaf age, and stored at $-20^{\circ} \mathrm{C}$ until chasmothecia developmental stages (primordia, immature, and mature) could be enumerated. Chasmothecia from each of the 10 leaves collected were counted from a transect along the leaf midvein. Chasmothecia were classified as primordia if they formed small white spheres without lipid accumulation; immature if they were yellow to orange, signifying that lipids were accumulating; and mature if they were brown to dark brown-black.

Data analysis. The relationship of the mating type presence in a given sample (Mat 1-1 [M1], Mat 1-2 [M2], and both Mat 1-1 and 1-2 [M3]) within canopy layers and across sampling periods (early, mid, and late season collection) was assessed using a multinomial logistic regression in the nnet package (Venables and Ripley 2002), and a log odds ratio analysis was used to compare mating type relationship with sampling time and canopy height. Area under chasmothecia production curves (AUCPC) were developed for chasmothecia initiation experiments. AUCPC values were compared using a linear mixed effects model with the lme4 package (Bates et al. 2015) in $\mathrm{R}$ version 3.2.1 ( $\mathrm{R}$ Core Team 2016). A repeated measures mixed effects model analysis was also conducted on chasmothecia development for each trial using the nlme (Pinheiro et al. 2017) and MASS (Venables and Ripley 2002) packages. The correlation of each measurement over time (days postinoculation) was added to a Poisson regression model with random slopes for each replication, plant and leaf combination.

\section{Results}

Mating type survey. In all three years, a mix of both Mat 1-1 and 1-2 mating types were found to be present within samples (on the same $71 \mathrm{~mm}^{2}$ sampling dots) at early (20\%), middle (54\%), and late $(65 \%)$ samplings. However, chasmothecia primordia were not observed until August 23, 2013, August 28, 2014, and July 28, 2015, shortly after véraison occurred. The ratio of M1 to M2 of all samples collected was 3:5, and the distribution within the canopy varied by collection period (early, middle, or late) and canopy position (Fig. 1). M2 frequency was always significantly greater or equal to the frequency of M1 across all canopy levels and sampling periods (Fig. 1A). The frequency of M3 (mix of mating types) was significantly less than M1 at early sampling periods, but was greater than or equal to M1 frequency at later sampling dates (Fig. 1B). M3 frequency was not significantly different from M2 at early sampling periods from all canopy heights, but significantly less than M2 at later sampling

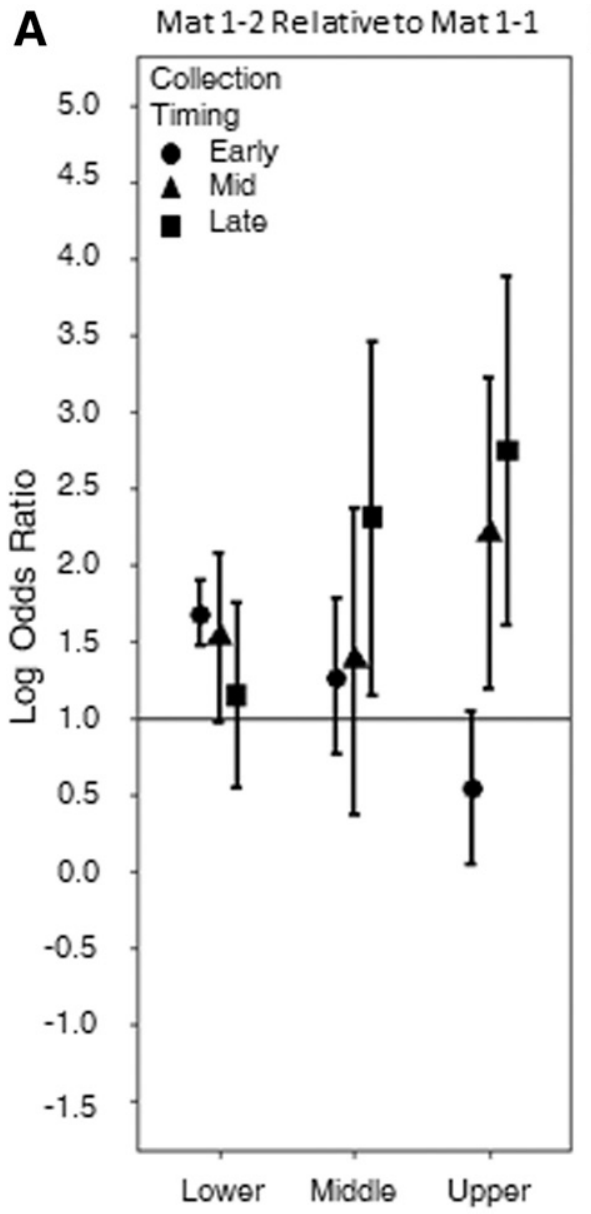

B Mat 1-1 \& Mat 1-2 Relative to Mat 1-1 C Mat 1-2 Relative to Mat 1-1 \& Mat 1-2
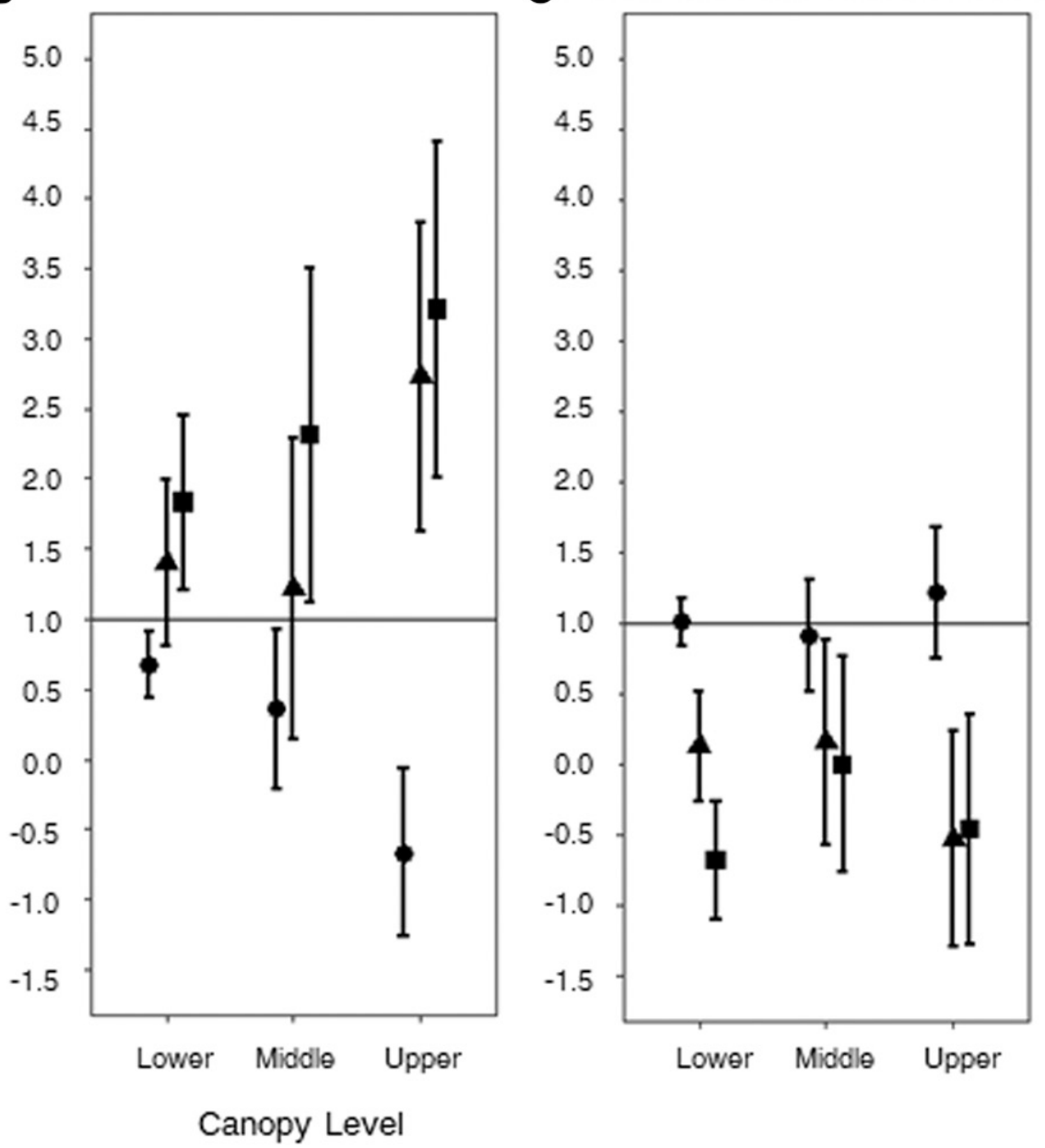

Fig. 1. Log odds ratio of the occurrence of Mat 1-2 relative to Mat 1-1 (A), both Mat 1-1 and 1-2 relative to Mat 1-1 (B), and Mat 1-2 relative to both Mat 1-1 and 1-2 (C) at early, mid, and late season collections of Erysiphe necator lesions from lower, middle, and upper canopy heights. Data were compared using a multinomial logistic model analysis with the nnet package (Venables and Ripley 2002) in R version 3.4.2 (R Core Team 2016). Points are log odds ratios and bars are 95\% confidence intervals around that ratio. Confidence intervals crossing the threshold line $(y=1)$ indicates no difference between the frequency of mating types. 
periods (Fig. 1C). The $\log$ odds of the occurrence of M2 relative to M1 (Fig. 1A) increased within the upper canopy as the season progressed $(P<0.03)$, but showed no significant seasonal trends in the lower and middle canopy. The log odds of the occurrence of M3 relative to M1 (Fig. 1B) increased as the season progressed at all canopy positions and with greater differences seen as canopy height increased $(P<0.04)$. The log odds of the occurrence of M2 relative to M3 (Fig. 1C) decreased as the season progressed $(P<$ $0.001)$, but canopy position had no impact on the ratio $(P>0.48)$. Sequencing of mating type PCR amplicons yielded only E. necatorspecific DNA sequences, indicating that the mating type primers used were species-specific.

Effect of temperature on chasmothecia development. Treatments between 10 and $25^{\circ} \mathrm{C}$ all produced chasmothecia primordia within 3 weeks of inoculation, and chasmothecia were not produced at 5,30 , or $35^{\circ} \mathrm{C}$ (Fig. 2). The AUCPC of the $10^{\circ} \mathrm{C}$ temperature treatment was $19.08 \pm 19.08$, the $15^{\circ} \mathrm{C}$ was $153.22 \pm 107.78$, the $20^{\circ} \mathrm{C}$ was $289.93 \pm 5.19$, and the $25^{\circ} \mathrm{C}$ was $5.19 \pm 5.19$. The AUCPC at $20^{\circ} \mathrm{C}$ was significantly greater than $5,10,25,30$, and $35^{\circ} \mathrm{C}(P=$ $0.05)$, and the AUCPC at $15^{\circ} \mathrm{C}$ was not significantly different from $20^{\circ} \mathrm{C}(P=0.31)$. Because no chasmothecia were found at 5 or $35^{\circ} \mathrm{C}$, they were removed from the repeated measures analysis. The repeated measures analysis showed similar results to AUCPC comparisons (Fig. 3), whereby chasmothecia production at 15 and $20^{\circ} \mathrm{C}$ was significantly greater than at other temperatures $(P \leq 0.02)$.

Effect of photoperiod on chasmothecia development. All plants with $E$. necator colonies subjected to photoperiod shift treatments had chasmothecia primordia develop within 3 weeks of initial inoculation (Fig. 4). The AUCPC of the short-to-short photoperiod treatment was $157.28 \pm 51.40$, the short-to-long photoperiod shift treatment was $577.08 \pm 56.68$, the long-to-short photoperiod shift treatment was $110.81 \pm 41.67$, and the maintained long-to-long photoperiod treatment was $283.78 \pm 176.80$. The AUCPC of short-tolong photoperiod and long-to-short photoperiod treatments were significantly different $(P=0.03)$, and no significant differences between other photoperiod treatment AUCPCs $(P>0.05)$ were observed. Chasmothecia development at the short-to-long photoperiod was significantly greater than at the short-to-short photoperiod $(P \leq 0.001)$ in the repeated measures analysis (Fig. 5).

Effect of plant stress on chasmothecia initiation. All treatments produced chasmothecia primordia by early September (BBCH 85) in both 2013 (Fig. 6A) and 2014 (Fig. 6B). There was no significant difference in the number of primordia, immature, or mature

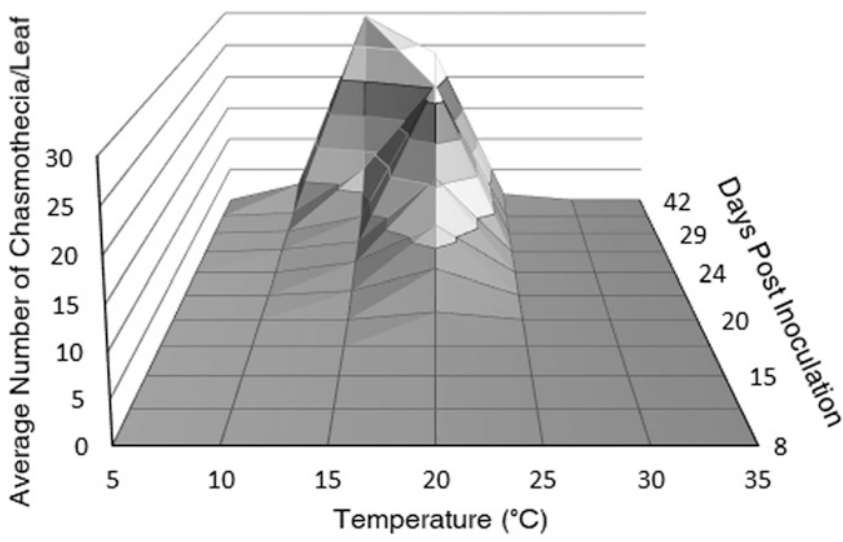

Fig. 2. Chasmothecia initiation and production on Chardonnay grapevine seedlings inoculated with Mat 1-1 and Mat 1-2 of Erysiphe necator and incubated in growth chambers under different constant temperature treatments $\left(5-35^{\circ} \mathrm{C}\right)$ at $60 \%$ relative humidity and 16 -h day lengths. No chasmothecia were produced at 5,30 , or $35^{\circ} \mathrm{C}$. The area under chasmothecia production curves (AUCPC) of the $10^{\circ} \mathrm{C}$ temperature treatment was $19.08 \pm 19.08$, the $15^{\circ} \mathrm{C}$ was $153.22 \pm 107.78$, the $20^{\circ} \mathrm{C}$ was $289.93 \pm 5.19$, and the $25^{\circ} \mathrm{C}$ was $5.19 \pm 5.19$. The AUCPC at $20^{\circ} \mathrm{C}$ was significantly different than $5,10,25,30$, and $35^{\circ} \mathrm{C}(P=0.05)$, but not significantly different from $15^{\circ} \mathrm{C}(P=0.31)$. chasmothecia produced $(P>0.05)$. There were no significant differences in chasmothecia initiation between stress treatments in either 2013 or $2014(P>0.5)$ (Fig. 6). Girdled canes showed signs of healing and recovery from girdling treatments approximately 1 month after treatments were executed. Premature leaf drop was also not observed in ABA treatments.

\section{Discussion}

Despite the presence of both mating types within a $71 \mathrm{~mm}^{2}$ area throughout the growing season, chasmothecia formation was not observed in the field until BBCH 85 in all three years of this study. This is in contrast to previous work conducted on chasmothecia initiation of E. necator (Evans et al. 1997; Gadoury and Pearson 1988) and other powdery mildews (Byford and Bentley 1976; Smith 1970), where chasmothecia initiation was reported to occur whenever mating types came into contact. However, these results are similar to the late-season development of E. necator chasmothecia described in other regions (Bulit and Lafon 1978; Legler et al. 2014), in other powdery mildew systems (Jarvis et al. 2002), or when plant tissues are maintained under stressful conditions (Evans et al. 1997). Evans et al. (1997) observed that E. necator chasmothecia did not form on tissue culture plantlets inoculated with both mating types with $12 \mathrm{~h}$ photoperiod; however, when plantlets were exposed to continuous light or moved to a greenhouse, chasmothecia primordia were initiated. They concluded that temperature, photoperiod, and light intensity could be factors and speculated that plant stress could be a factor. Similarly, Asalf et al. (2013) concluded that $P$. aphanis chasmothecia production was regulated by temperature, although they could not rule out differences in photosynthate accumulation in leaves at the lower temperatures.

Temperature treatments between 10 and $25^{\circ} \mathrm{C}$ had no impact on the timing of chasmothecia initiation (data not shown), and chasmothecia production occurred at all temperatures except 5 and $35^{\circ} \mathrm{C}$ (Figs. 2 and 3). This response is similar to temperature growth limitations of E. necator hyphae below $6^{\circ} \mathrm{C}$ and above $32^{\circ} \mathrm{C}$ (Delp 1954; Peduto et al. 2013), and reduced chasmothecia production may be related to the reduced hyphal growth. The temperature did affect the total number of chasmothecia produced (Figs. 2 and 3), which is consistent with previous reports of chasmothecia development (Gadoury and Pearson 1988; Legler et al. 2014). The optimal growth of E. necator similarly follows the optimal growth of $V$. vinifera, in which peak photosynthesis rates occur between 20 and $30^{\circ} \mathrm{C}$ with an optimum ambient temperature of $25^{\circ} \mathrm{C}$ and leaf surface temperature of $20^{\circ} \mathrm{C}$ (Greer and Weedon 2012). Because grapevines are adaptive to environmental conditions, such as light intensity and temperature,

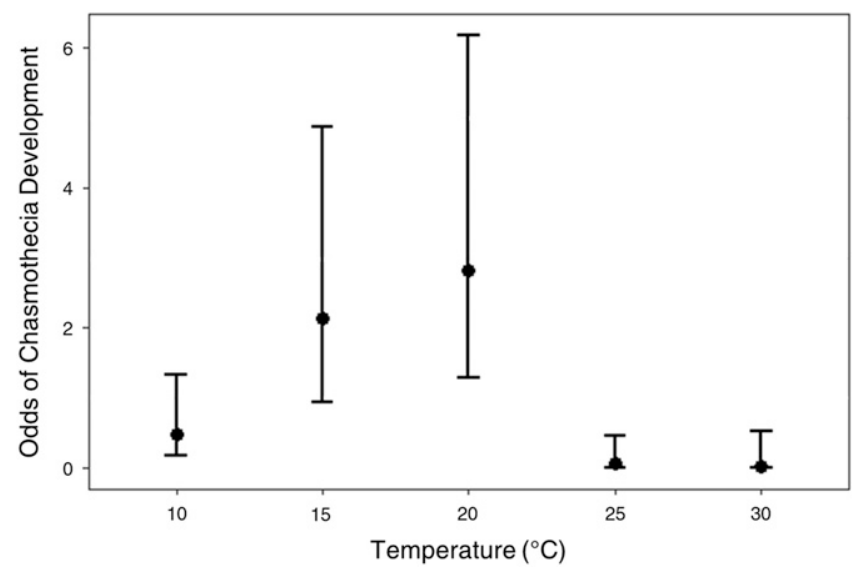

Fig. 3. The odds of chasmothecia development on Chardonnay grapevine seedlings inoculated with Mat 1-1 and Mat 1-2 of Erysiphe necator that were incubated under constant temperature treatments $\left(5-35^{\circ} \mathrm{C}\right)$. Because no chasmothecia formed at 5 or $35^{\circ} \mathrm{C}$, risk could not be estimated for these temperatures, and these temperatures were removed from this analysis. Chasmothecia production at 15 and $20^{\circ} \mathrm{C}$ was significantly different from other temperatures $(P \leq 0.02)$. 
affecting photosynthetic response (Larcher 2003; Zufferey et al. 2000), V. vinifera seedling and detached leaf growth optima in a growth chamber may be different from those found in field environments.

Over the course of the growth chamber experiments, the lower leaves that were inoculated rapidly abscised and died on the potted vines. This senescence could be due to physiological differences between seedlings and mature vines (Ficke et al. 2002, 2003; Gadoury et al. 2003; Gee et al. 2008), hormone regulation (Boneh et al. 2012; Davies et al. 1997; Tanaka et al. 2006), or carbohydrate source or sink relationships (Merry et al. 2013). Plant stresses, such as tissue age, temperature stress, water stress, or nutrient stress, have also been correlated with hormone regulation and carbohydrate metabolism (Gupta and Kaur 2005; Patakas and Noitsakis 2001), and potted seedlings are likely affected by different stresses than established grapevines in the field. The use of $10-\mathrm{cm}$ pots may have also restricted root growth and altered leaf physiology. Root restriction

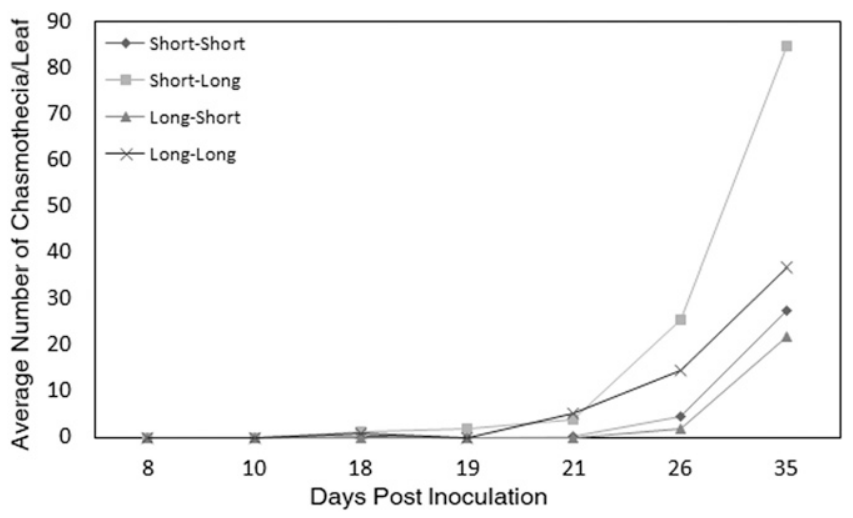

Fig. 4. Chasmothecia initiation and production on Chardonnay grapevine seedlings inoculated with Mat 1-1 and Mat 1-2 of Erysiphe necator and incubated in growth chambers at $60 \%$ relative humidity and $20^{\circ} \mathrm{C}$ under different photoperiod change treatments: short day ( $8 \mathrm{~h}$ light/16 h dark) to short day (diamond), short-to-long day (16 h light/8 h dark) (square), long-to-short day (triangle), and long-to-long day ( $\mathrm{x}$ ). The area under chasmothecia production curve (AUCPC) of the short-to-short day photoperiod treatment was $157.28 \pm 51.40$, the short-to-long day treatment was $577.08 \pm 56.68$, the long-to-short day treatment was $110.81 \pm 41.67$, and the longto-long day treatment was $283.78 \pm 176.80$. The AUCPC of the short-to-long day and long-to-short day photoperiod treatments were significantly different $(P=0.02)$, and no significant differences between other photoperiod treatments were observed $(P>0.05)$.

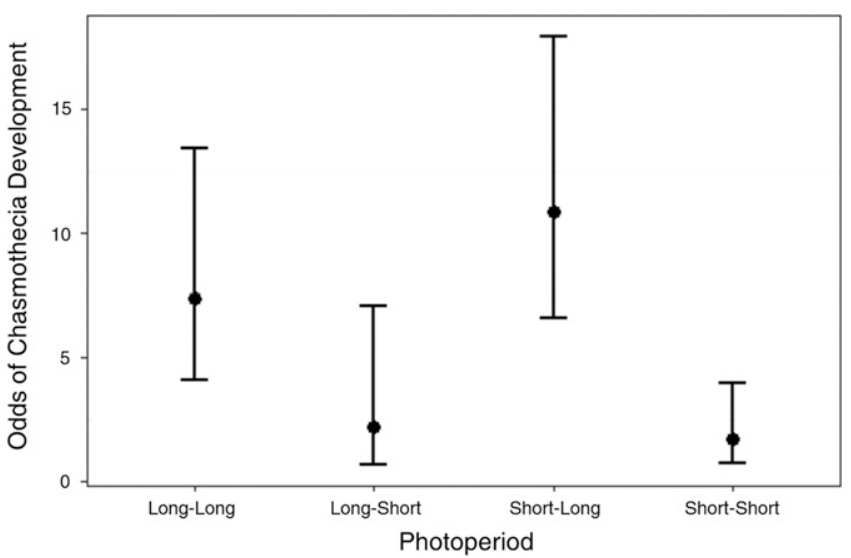

Fig. 5. The risk of chasmothecia development on Chardonnay grapevine seedlings inoculated with Mat 1-1 and Mat 1-2 of Erysiphe necator that were incubated under constant temperature $\left(20^{\circ} \mathrm{C}\right)$ and humidity $(60 \%)$ at different light regimes: long $(16$ h)-to-long day, long-to-short day (8 h), short-to-short day, and short-to-long day. Chasmothecia development at short-to-long and short-to-short photoperiods was significantly different $(P \leq 0.001)$. has been observed in other plant systems to decreased plant growth and increase accumulation of abscisic acid (Carmi 1995; Krizek et al. 1985) and starch in leaves (Al-Debei and Mugnai 2011; Zhu et al. 2006). Starch has been shown to favor ascocarp production in several other ascomycetes (Moore-Landecker 1992) and does not accumulate in grape leaves until photosynthate begins to accumulate (Mullins et al. 1992). In mature vines, berries are a strong sink until after véraison (Hunter and Visser 1988), which could limit foliar photosynthate and starch accumulation.

Photoperiod shift did not affect the timing of chasmothecia primordia initiation, but the shifting of photoperiod from short-tolong duration resulted in significantly more chasmothecia production than short-to-short treatments (Fig. 4). These results are most likely related to the increased amount of photosynthate available for pathogen growth and chasmothecia production with long photoperiod (Chaumont et al. 1994). It is also possible that the lower chasmothecia production in the short photoperiod treatments was a result of dormancy responses in grapevine (Fennell and Hoover 1991). These results are contrary to our hypothesis that shortening photoperiod after
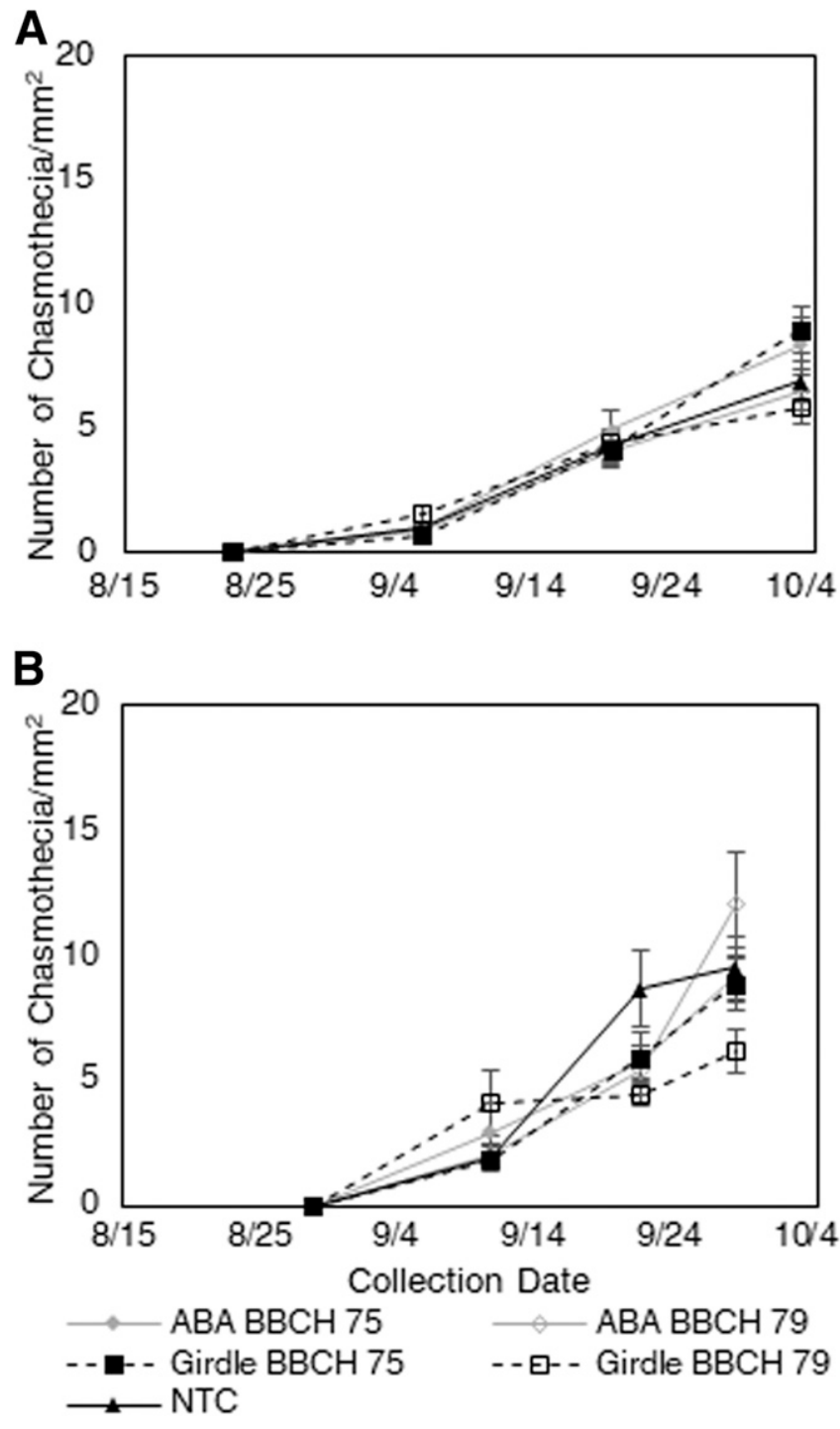

Fig. 6. Chasmothecia production curves observed in 2013 (A) and 2014 (B). The field was inoculated with both mating types (Mat 1-1 and Mat 1-2) to ensure their presence in the field at BBCH 19 of each year. Host senescence induction treatments with abscisic acid (ABA, gray solid lines) and girdling treatments (black dashed lines) applied at two time points (BBCH 75, solid marker; $\mathrm{BBCH} 79$, outlined marker) showed no significant differences in the development of chasmothecia $(P>0.1)$. Initial chasmothecia primordia were observed on August 23, 2013 and August 28, 2014. 
June 21 in the northern hemisphere could stimulate chasmothecia production. These results seem to indicate that factors other than photoperiod stimulate chasmothecia production.

A potential mechanism for the induction of chasmothecia of powdery mildews may be host senescence (Homma 1937) or water stress that also occurs at the end of the growing season. Inducing a water stress response or senescence stress response in the host vines was not achieved in the field trial in this study, and despite girdling and ABA treatments, chasmothecia developed at the same time in all treatment plots. This may be due to the recovery of the host to girdling treatments, which was observed within 30 days after treatments were made. The high vigor of grapevine plants at the research vineyard due to a water table may have allowed the vine to cope with damaged xylem tissue from the girdling treatment. Host senescence was not observed in the ABA treatments, and may be due to the inhibition of ABA by auxin production prior to the end of the growing season (Davies et al. 1997; Tanaka et al. 2006). While host senescence or water stress failed to produce the desired outcome in this study, host senescence or other host stresses may still be a factor in the initiation of chasmothecia.

There is some indication that the Mat 1-1 mating type is less ecologically fit than the Mat 1-2 type. In the early sampling periods, there was an approximately 1:1 ratio of each mating type, which agrees with the findings from previous studies (Brewer et al. 2011; Cortesi et al. 2004; Gadoury and Pearson 1988, 1991) and expectations from a genetic segregation perspective. However, the frequency of Mat 1-1 alone relative to Mat 1-2 decreased over the growing season and within the upper canopy $(P<0.03)$, which could potentially be related to the fecundity of the mating types under different environmental conditions or inherent to the mating type. In the early sampling period, when temperatures are cooler with a shorter photoperiod, Mat 1-1 was more frequent in samples in the upper canopy but became less frequent as temperature increased and radiant energy absorbed by the leaves increased. All of these factors could influence pathogen growth and perhaps mating types differentially; however, this speculation needs to be investigated experimentally. Flag shoots were also present in the research area, which may have skewed the relative abundance of mating types; however, the decrease in the ratio of Mat 1-1 to Mat 1-2 is not explained by flag shoot presence. Canopy height also appeared to be influential in the presence of Mat 1-2 increasing $(P<0.03)$, which may be related to higher UV exposure or leaf surface temperature in the canopy (Austin and Wilcox 2012; Bailey 2018). The number of Tough-Spots samples containing a mix of both Mat 1-1 and 1-2 remained relatively constant as the season progressed, indicating that mating type proximity likely stayed constant as well. The probability of hyphae from each mating type overlapping (e.g., in contact at each sampling time) within 2 weeks (Gadoury and Pearson 1988) of sample collection is highly likely, given the radial growth pattern of $E$. necator colonies (Gadoury et al. 2012), the morphology of colonies selected (e.g., colonies appearing to be circular), and the limited sample area $\left(71 \mathrm{~mm}^{2}\right)$. These results suggest that proximity to mating type is not the sole driver for chasmothecia initiation.

Even though the results of this study were unable to correlate other factors to chasmothecia initiation, they do suggest that factors other than mating type proximity influence the late development of chasmothecia in the Pacific Northwest growing region. Host chemical signaling, such as host senescence hormone signaling or hormonal shifts, may provide an explanation for the late development of grape powdery mildew chasmothecia. Assessment of hormonal influence on E. necator chasmothecia initiation, however, may be difficult to assess on grapevine due to the inability to grow the fungus on artificial media and exclude other host processes, like carbohydrate reallocation, that may influence fungal growth and development. Carbohydrate resources have been previously implicated in the severity of E. necator infection (Merry et al. 2013), and reallocation of resources from leaf tissue to other portions of the plant may influence the production of chasmothecia. During berry ripening, carbohydrates rapidly increase in fruit (Iland et al. 2011), and significant carbohydrate reallocation from leaves may not occur in established vines until véraison (BBCH 83) in the Willamette Valley of Oregon due to high vigor of vines. In regions with greater stress on vines due to environmental conditions, carbohydrates may shift in response to stress conditions (Roitsch 1999), which may cause chasmothecia to develop sooner than what is observed in more temperate environments. Further investigation of the host-derived factors influencing chasmothecia initiation is required to better predict development of chasmothecia across various regions and differing environmental conditions.

\section{Acknowledgments}

We thank T. Schappe, A. Albrecht, C. Provence, C. Gorman, B. Warneke, and B. Williams for technical support. We also thank anonymous reviewers for their helpful suggestions to improve the manuscript. The use of trade, firm, or corporation names in this publication is for the information and convenience of the reader. Such use does not constitute an official endorsement or approval by the United States Department of Agriculture or the Agricultural Research Service of any product or service to the exclusion of others that may be suitable.

\section{Literature Cited}

Al-Debei, H., and Mugnai, S. 2011. Starch accumulation in the leaves of rootrestricted pepper affects plant growth by a feedback-inhibition of the photosynthesis. Adv. Hortic. Sci. 25:253-259.

Asalf, B., Gadoury, D. M., Tronsmo, A. M., Seem, R. C., Cadle-Davidson, L., Brewer, M. T., and Stensvand, A. 2013. Temperature regulates the initiation of chasmothecia in powdery mildew of strawberry. Phytopathology 103:717-724.

Austin, C. N., and Wilcox, W. F. 2012. Effects of sunlight exposure on grapevine powdery mildew development. Phytopathology 102:857-866.

Bailey, B. N. 2018. A reverse ray-tracing method for modelling the net radiative flux in leaf-resolving plant canopy simulations. Ecol. Modell. 368:233-245.

Bates, D., Maechler, M., Bolker, B., and Walker, S. 2015. Fitting Linear MixedEffects Modes Using lme4. J. Stat. Softw. 67:1-48.

Boneh, U., Biton, I., Schwartz, A., and Ben-Ari, G. 2012. Characterization of the ABA signal transduction pathway in Vitis vinifera. Plant Sci. 187:89-96.

Bowles, D. J. 1990. Defense-related proteins in higher plants. Annu. Rev. Biochem. 59:873-907.

Braun, U., and Takamatsu, S. 2013. Phylogeny of Erysiphe, Microsphaera, Uncinula (Erysiphaceae) and Cystotheca, Podosphaera, Sphaerotheca (Cystotheceae) inferred from rDNA ITS sequences-some taxonomic consequences. Schlechtendalia (Halle) 4:1-33.

Brewer, M. T., Cadle-Davidson, L., Cortesi, P., Spanu, P. D., and Milgroom, M. G. 2011. Identification and structure of the mating-type locus and development of PCR-based markers for mating type in powdery mildew fungi. Fungal Genet. Biol. 48:704-713.

Brewer, M. T., and Milgroom, M. G. 2010. Phylogeography and population structure of the grape powdery mildew fungus, Erysiphe necator, from diverse Vitis species. BMC Evol. Biol. 10:268.

Bulit, J., and Lafon, R. 1978. Powdery mildew of the vine. Pages 525-548 in:The Powdery Mildews. D. M. Spencer, ed. Academic Press Inc., Cambridge, MA.

Byford, W., and Bentley, K. 1976. Cleistothecia of Erysiphe betae in England. Trans. Br. Mycol. Soc. 67:544-545.

Caffi, T., Legler, S. E., Rossi, V., and Bugiani, R. 2012. Evaluation of a warning system for early-season control of grapevine powdery mildew. Plant Dis. 96:104-110.

Caffi, T., Rossi, V., Legler, S. E., and Bugiani, R. 2011. A mechanistic model simulating ascosporic infections by Erysiphe necator, the powdery mildew fungus of grapevine. Plant Pathol. 60:522-531.

Carmi, A. 1995. Growth, water transport and transpiration in root-restricted plants of bean, and their relation to abscisic acid accumulation. Plant Sci. 107:69-76.

Chaumont, M., Morot-Gaudry, J.-F., and Foyer, C. H. 1994. Seasonal and diurnal changes in photosynthesis and carbon partitioning in Vitis vinifera leaves in vines with and without fruit. J. Exp. Bot. 45:1235-1243.

Cortesi, P., Bisiach, M., Ricciolini, M., and Gadoury, D. M. 1997. Cleistothecia of Uncinula necator-an additional source of inoculum in Italian vineyards. Plant Dis. 81:922-926.

Cortesi, P., Ottaviani, M.-P., and Milgroom, M. G. 2004. Spatial and genetic analysis of a flag shoot subpopulation of Erysiphe necator in Italy. Phytopathology 94:544-550.

Davies, C., Boss, P. K., and Robinson, S. P. 1997. Treatment of grape berries, a nonclimacteric fruit with a synthetic auxin, retards ripening and alters the expression of developmentally regulated genes. Plant Physiol. 115:1155-1161.

Delp, J. 1954. Effect of temperature and humidity on the grape powdery mildew fungus. Phytopathology 44:615-626.

Evans, K., Scott, E., and Whisson, D. 1997. Heterothallism among South Australian clonal lines of Uncinula necator. Australas. Plant Pathol. 26:10-20.

Fennell, A., and Hoover, E. 1991. Photoperiod influences growth, bud dormancy, and cold acclimation in Vitis labruscana and V. riparia. J. Am. Soc. Hortic. Sci. 116:270-273.

Ficke, A., Gadoury, D. M., and Seem, R. C. 2002. Ontogenic resistance and plant disease management: A case study of grape powdery mildew. Phytopathology 92:671-675. 
Ficke, A., Gadoury, D. M., Seem, R. C., and Dry, I. B. 2003. Effects of ontogenic resistance upon establishment and growth of Uncinula necator on grape berries. Phytopathology 93:556-563.

Gadoury, D. M., Cadle-Davidson, L., Wilcox, W. F., Dry, I. B., Seem, R. C., and Milgroom, M. G. 2012. Grapevine powdery mildew (Erysiphe necator): A fascinating system for the study of the biology, ecology and epidemiology of an obligate biotroph. Mol. Plant Pathol. 13:1-16.

Gadoury, D. M., and Pearson, R. C. 1988. Initiation, development, dispersal and survival of cleistothecia of Uncinula necator in New York vineyards. Phytopathology 78:1413-1421.

Gadoury, D. M., and Pearson, R. C. 1990. Ascocarp dehiscence and ascospore discharge in Uncinula necator. Phytopathology 80:393-401.

Gadoury, D. M., and Pearson, R. C. 1991. Heterothallism and pathogenic specialization in Uncinula necator. Phytopathology 81:1287-1293.

Gadoury, D. M., Seem, R. C., Ficke, A., and Wilcox, W. F. 2003. Ontogenic resistance to powdery mildew in grape berries. Phytopathology 93:547-555.

Gee, C. T., Gadoury, D. M., and Cadle-Davidson, L. 2008. Ontogenic resistance to Uncinula necator varies by genotype and tissue type in a diverse collection of Vitis spp. Plant Dis. 92:1067-1073.

Gee, L. M., Stummer, B. E., Gadoury, D. M., Biggins, L. T., and Scott, E. S. 2000. Maturation of cleistothecia of Uncinula necator (powdery mildew) and release of ascospores in southern Australia. Aust. J. Grape Wine Res. 6:13-20.

Greer, D. H., and Weedon, M. M. 2012. Modelling photosynthetic responses to temperature of grapevine (Vitis vinifera cv. Semillon) leaves on vines grown in a hot climate. Plant Cell Environ. 35:1050-1064.

Gupta, A. K., and Kaur, N. 2005. Sugar signalling and gene expression in relation to carbohydrate metabolism under abiotic stresses in plants. J. Biosci. 30: 761-776.

Homma, Y. 1937. Erysiphaceae of Japan. J. Fac. Agric. Hokkaido Univ. 38: $183-461$.

Hunter, J., and Visser, J. 1988. The effect of partial defoliation, leaf position and developmental stage of the vine on the photosynthetic activity of Vitis vinifera L. cv Cabernet Sauvignon. S. Afr. J. Enol. Vitic. 9:9-15.

Iland, P., Dry, P., Proffitt, T., and Tyerman, S. 2011. The grapevine. Pages 1-13 in: The Grapevine: From the Science to the Practice of Growing Vines for Wine. Patrick Iland Wine Promotions Pty Ltd, Adelaide, South Australia.

Jailloux, F., Thind, T., and Clerjeau, M. 1998. Release, germination, and pathogenicity of ascospores of Uncinula necator under controlled conditions. Can. J. Bot. 76:777-781.

Jarvis, W. R., Gubler, W. D., and Grove, G. G. 2002. Epidemiology of powdery mildews in agricultural pathosystems. Pages 169-199 in: The Powdery Mildews A Comprehensive Treatise. B. R.R. Belanger, W. R. Dik, A. J. T. L. W. Carver, ed. The American Phytopathological Society, St. Paul, Minnesota.

Kottek, M., Grieser, J., Beck, C., Rudolf, B., and Rubel, F. 2006. World map of the Köppen-Geiger climate classification updated. Meteorol. Z. (Berl.) 15:259-263.

Krizek, D. T., Carmi, A., Mirecki, R. M., Snyder, F. W., and Bunce, J. A. 1985. Comparative effects of soil moisture stress and restricted root zone volume on morphogenetic and physiological responses of soybean [Glycine max (L.) Merr.] J. Exp. Bot. 36:25-38

Larcher, W. 2003. Physiological plant ecology: Ecophysiology and stress physiology of functional groups. Springer Science \& Business Media

Legler, S. E., Caffi, T., and Rossi, V. 2012. A nonlinear model for temperaturedependent development of Erysiphe necator chasmothecia on grapevine leaves. Plant Pathol. 61:96-105.

Legler, S. E., Caffi, T., and Rossi, V. 2014. A model for the development of Erysiphe necator chasmothecia in vineyards. Plant Pathol. 63:911-921.

León, J., Rojo, E., and Sánchez-Serrano, J. J. 2001. Wound signalling in plants. J. Exp. Bot. 52:1-9.
Lorenz, D. H., Eichhorn, K. W., Bleiholder, H., Klose, R., Meier, U., and Weber, E. 1995. Growth stages of the grapevine: Phenological growth stages of the grapevine (Vitis vinifera L. ssp. vinifera)-codes and descriptions according to the extended BBCH scale. Aust. J. Grape Wine Res. 1:100-103.

Mendgen, K., and Hahn, M. 2002. Plant infection and the establishment of fungal biotrophy. Trends Plant Sci. 7:352-356.

Merry, A., Evans, K., Corkrey, R., and Wilson, S. 2013. Coincidence of maximum severity of powdery mildew on grape leaves and the carbohydrate sink-tosource transition. Plant Pathol. 62:842-850.

Moore-Landecker, E. 1992. Physiology and biochemistry of ascocarp induction and development. Mycol. Res. 96:705-716.

Moyer, M. M., Gadoury, D. M., Wilcox, W. F., and Seem, R. C. 2014. Release of Erysiphe necator ascospores and impact of early season disease pressure on Vitis vinifera fruit infection. Am. J. Enol. Vitic. 65:315-324.

Mullins, M. G., Bouquet, A., and Williams, L. E. 1992. Biol Grape. Cambridge University Press, Cambridge, IL.

Patakas, A., and Noitsakis, B. 2001. Leaf age effects on solute accumulation in water-stressed grapevines. J. Plant Physiol. 158:63-69.

Peduto, F., Backup, P., Hand, E. K., Janousek, C. N., and Gubler, W. D. 2013 Effect of high temperature and exposure time on Erysiphe necator growth and reproduction: Revisions to the UC Davis Powdery Mildew Risk Index. Plant Dis. 97:1438-1447.

Pinheiro, J., Bates, D., DebRoy, S., Sarkar, D., and Team, R. C. 2017. _nlme: Linear and Nonlinear Mixed Effects Models_. R Ver 3.1-131.

Pscheidt, J. W., Wittig, H. P. P., Wallace, L. D., Hall, T., and Mahaffee, W. 2000. Evaluation of three grape powdery mildew forecasting programs in Corvallis, Oregon, USA. SARDI Research Report Series. S. A. Margarey Thiele, K. L. Tschirpig, R. W. Emmett, K. Clarke, and R. D. Margarey, eds. PIRSA, Adelaide, Australia.

Quinn, J., and Powell, C., Jr. 1982. Effects of temperature, light, and relative humidity on powdery mildew of begonia. Phytopathology 72:480-484.

R Core Team. 2016. R: A language and environment for statistical computing. R Foundation for Statistical Computing, Vienna, Austria.

Roitsch, T. 1999. Source-sink regulation by sugar and stress. Curr. Opin. Plant Biol. 2:198-206.

Rossi, V., Caffi, T., and Legler, S. E. 2010. Dynamics of ascospore maturation and discharge in Erysiphe necator, the causal agent of grape powdery mildew. Phytopathology 100:1321-1329.

Skriver, K., and Mundy, J. 1990. Gene expression in response to abscisic acid and osmotic stress. Plant Cell 2:503-512.

Smith, C. 1970. Production of powdery mildew cleistocarps in a controlled environment. Trans. Br. Mycol. Soc. 55:355-365.

Tanaka, Y., Sano, T., Tamaoki, M., Nakajima, N., Kondo, N., and Hasezawa, S. 2006. Cytokinin and auxin inhibit abscisic acid-induced stomatal closure by enhancing ethylene production in Arabidopsis. J. Exp. Bot. 57:2259-2266.

Thiessen, L. D., Neill, T. M., and Mahaffee, W. F. 2018. Assessment of Erysiphe necator ascospore release models for use in the Mediterranean climate of Western Oregon. Plant Dis. 102:1500-1508.

Thomas, C. S., Gubler, W. D., and Leavitt, G. 1994. Field testing of a powdery mildew disease forecast model on grapes in California. Phytopathology 84 1070 (abstr.).

Venables, W. N., and Ripley, B. D. 2002. Modern Applied Statistics with S, 4th ed. Springer, New York.

Zhu, L., Wang, S., Yang, T., Zhang, C., and Xu, W. 2006. Vine growth and nitrogen metabolism of 'Fujiminori' grapevines in response to root restriction. Sci. Hortic. (Amsterdam) 107:143-149.

Zufferey, V., Murisier, F., and Schultz, H. 2000. A model analysis of the photosynthetic response of Vitis vinifera L. cvs Riesling and Chasselas leaves in the field: I. Interaction of age, light and temperature. Vitis 39:19-26. 